\title{
EXPLORE
}

\section{Digitalisasi Presensi Kelas Offline Berbasis Radio Frequency Identification (RFID)}

\author{
Erlangga Erlangga, Yeni Oktavia, Robby Yuli Endra, Ahmad Cucus, Fenty Ariani \\ Program Studi Sistem Informasi, Program Studi Informatika \\ Fakultas Ilmu Komputer, Universitas Bandar Lampung \\ Bandar Lampung, Indonesia \\ erlangga@ubl.ac.id, yeniokta56@gmail.com,robby.yuliendra@ubl.ac.id, \\ ahmad.cucus@ubl.ac.id_fenty.ariani@ubl.ac.id
}

\begin{abstract}
The current technological development is very rapid, especially in the field of information technology. Increasingly complex human needs demand that everything be done quickly and efficiently. In addition, the level of accuracy is prioritized, especially in data processing so that appropriate information is obtained, including in attendance data processing. So far, the conventional attendance system still uses a written system, by signing the attendance sheet. The problem is the amount of paper used, so there will be a buildup of files. Meanwhile, checking the data and the attendance process itself is quite slow because it has to be checked one by one. Data storage that is not computerized often experiences data loss. The purpose of this research is to reduce excessive paper use, reduce the cost of purchasing paper, and help speed up the attendance process without having to double-check the attendance concerned. This presence system is equipped with database features so that the process of searching and storing data is more practical, structured and safe. Digitizing offline attendance using Radio Frequency Identification (RFID) technology can facilitate the processing of attendance data and can become a supporting medium in the smooth face-to-face attendance process.
\end{abstract}

Keywords: Digitalisasi Presensi, Absensi, Attendance Digitization, Radio Frequency Identification, RFID

\begin{abstract}
Abstrak- Perkembangan teknologi saat ini sangat pesat terkhusus dibidang teknologi informatika. Kebutuhan manusia yang semakin kompleks menuntut segala sesuatu harus dikerjakan dengan cepat dan efisien. Selain itu, tingkat keakuratan sangat diutamakan utamanya dalam pengolahan data sehingga didapat informasi yang tepat guna, tidak terkecuali dalam pengolahan data presensi. Sistem presensi konvensional selama ini masih menggunakan sistem tulis, dengan cara membubuhkan tanda tangan di lembar kehadiran. Permasalahannya adalah banyaknya penggunaan kertas sehingga akan terjadi penumpukan berkas. Sementara itu untuk melakukan pemeriksaan data dan proses presensi itu sendiri cukup lambat karena harus dicek satu per satu. Penyimpanan data yang tidak terkomputerisasi seringkali mengalami kehilangan data. Tujuan dari penelitian ini adalah untuk mengurangi penggunaan kertas yang berlebihan, menurunkan biaya pembelian kertas, dan membantu mempercepat proses presensi tanpa harus melakukan pengecekan ulang absen dari yang bersangkutan. Sistem presensi ini dilengkapi dengan fitur database sehingga proses pencarian dan penyimpanan data lebih praktis, terstruktur dan aman. Digitalisasi presensi offline ini menggunakan teknologi Radio Frequency Identification (RFID) dapat mempermudah dalam melakukan proses pengolahan data kehadiran dan dapat menjadi media pendukung dalam kelancaran proses presensi tatap muka langsung.
\end{abstract}

Kata Kunci: Digitalisasi Presensi, Absensi, Attendance Digitization, Radio Frequency Identification, RFID

\section{Pendahuluan}

Pertumbuhan pendidikan di Indonesia mengalami kemajuan yang signifikan. Hal ini terlihat dari banyaknya tempat pendidikan baik berbentuk perguruan tinggi, universitas, maupun lembaga kursus nonformal yang berorientasi pada kebutuhan industri. Dengan semakin banyaknya tempat pendidikan yang tersedia, menyebabkan terjadinya persaingan tersendiri antar tempat pendidikan. Berbagai cara digunakan oleh masingmasing tempat pendidikan untuk memenangkan persaingan. Salah satu cara yang dapat digunakan adalah dengan meningkatkan kualitas layanan agar pengguna dapat merasa puas atas layanan tersebut [1]. Termasuk salah satunya adalah layanan presensi kehadiran.

Sistem presensi di dunia pendidikan Indonesia utamanya yang berada jauh dari pusat kota masih banyak yang menggunakan lembar kertas kehadiran dengan cara membubuhkan tanda tangan langsung di lembar presensi. Permasalahan dalam sistem ini yaitu banyaknya penggunaan kertas yang notabenenya berhubungan dengan pembiayaan dan tak jarang penggunaan kertas tersebut berakhir pada penumpukan berkas. Permasalahan belum berhenti disitu, pengecekan data 
kehadiran cukup lambat karena harus dilakukan pemeriksaan satu per satu. Belum lagi tidak menutup kemungkinan akan terjadi manipulasi data kehadiran apabila pengawasan tidak dilakukan dengan baik. Selain itu penyimpanan data pun rentan rusak dan hilang. Sistem manajemen dokumen berbasis paperless efektif dan berguna di kantor untuk menyederhanakan proses dokumentasi itu sendiri. Hal ini dapat membantu menemukan informasi yang dibutuhkan dapat dilakukan lebih cepat, lebih baik, lebih murah, dan mengurangi dampak lingkungan (Green Computing)[2]. Oleh sebab itu dibutuhkan sebuah cara yang dapat mengatasi hal tersebut diatas. Penelitian ini mengusulkan sebuah sistem digitalisasi presensi offline dengan menggunakan teknologi sensor RFID.

Radio Frequency Identification (RFID) merupakan teknik identifikasi sebuah objek dengan memanfaatkan gelombang radio. Proses pengidentifikasian tersebut menggunakan RFID Reader sebagai alat pembaca RFID Transponder. RFID Transponder yang dikenal juga dengan RFID Tag atau RFID Card sendiri ditempelkan ke objek yang akan diidentifikasi. Setiap RFID Card memiliki nomor ID sehingga tidak ada yang memiliki nomor ID yang sama satu sama lain. Teknologi RFID terbilang cukup mudah digunakan dan cocok untuk aktivitas operasional pekerjaan yang membutuhkan serba otomatis, bersifat read and write, tidak membutuhkan kontak langsung atau jalur cahaya untuk mengoperasikannya, dapat berfungsi di berbagai lingkungan, dan dapat memberikan integritas data tingkat tinggi[3].

Penelitian sebelumnya menjelaskan bahwa presensi secara manual dapat mengganggu fokus siswa saat

\section{Metodologi}

\section{A. Tahap Penelitian}

Jenis penelitian yang digunakan adalah experimental research dengan langkah-langkah sebagai berikut:

1. Mengidentifikasi Permasalahan yaitu bagaimana membangun sistem presensi dengan menggunakan sensor RFID.

2. Memilih Subjek yaitu pengukuran parameter kecepatan, gelombang frekuansi radio.

3. Membuat Instrument untuk mendapat parameter penilaian kinerja sistem presensi, dilakukan pengujian dengan cara mensimulasikan sistem presensi dengan menggunakan perangkat RFID dengan sistem kontrol menggunakan Arduino.

4. Memilih Desain Penelitian yaitu dengan menggunakan Visual Studio 2013 yang akan diimplementasikan menjadi sistem presensi yang berbasis RFID.

5. Melakukan Eksekusi Prosedur yaitu dengan melakukan konfirgurasi dan pengukuran sensor RFID terhadap Microcontoller Arduino Uno.

6. Melakukan Analisis yaitu dengan memasukkan jenisjenis RFID Card pada sistem RFID yang sudah ditanamkan sistem. Kemudian dilanjutkan mendengarkan penjelasan, presensi manual juga dapat membuat antrian panjang ketika ratusan siswa harus mengisi formulir kehadiran. Dengan melakukan scanning langsung pada mesin presensi menggunakan RFID, maka pengolahan data dengan aplikasi akan menghasilkan informasi yang lebih akurat dibandingkan dengan apa yang dilakukan secara manual [4]. Presensi manual juga sering terjadi kesalahan dan dengan banyaknya jumlah data presensi tiap mata pelajaran untuk tiap siswa mengakibatkan proses tersebut tidak efektif dan tidak efisien. Dengan teknologi RFID ini, setiap siswa tidak perlu lagi mengetahui form presensi yang akan diidentifikasi secara otomatis oleh RFID Reader dan disimpan dalam sistem database[5]. Presensi manual juga sulit untuk dilakukan pemeriksaan untuk memastikan kehadiran siswa atau karyawan hadir atau tidak hadir. Teknologi RFID ini dapat menerapkan pemrosesan data secara nirkabel menggunakan frekuensi radio dengan lebih efisien daripada teknologi infra red yang digunakan oleh pembaca barcode (barcode reader) [3].

Tujuan sistem presensi dengan kartu RFID ini yaitu sebagai pengganti absensi kertas dengan suatu sistem portabel yang menggunakan kartu RFID, mengurangi penggunaan kertas yang berlebihan dan biaya penggunaan kertas serta sistem presensi dapat dilakukan dengan cepat, karena sistem ini sudah dilengkapi dengan fitur database sehingga proses penyimpanan lebih terstruktur dan aman. Bahasa pemrograman yang digunakan adalah Visual Studio 2013 dengan Database SQL Server Express 2012. Uji coba program menggunakan sample data di Universitas Bandar Lampung.

pengamatan dan pencatatan dari parameter yang terjadi pada saat simulasi sistem absensi RFID.

7. Memformulasikan Simpulan dari penelitian yang telah dilakukan.

\section{B. Pengumpulan Data}

Teknik pengumpulan data dilakukan dengan studi pustaka, wawancara dengan Kepala Bagian Pusat Komputer Universitas Bandar Lampung (Kabag. Puskom UBL), dan melakukan observasi pada sistem absensi untuk mendapatkan data yang akurat, pengambilan sampel penelitian. Sampel penelitian merupakan bagian dari jumlah dan karakteristik suatu populasi penelitian [6].

Sampel pada penelitian ini adalah di perguruaan tinggi yaitu Universitas Bandar Lampung (UBL) dengan populasinya adalah mahasiswa dan dosen. Sebagai uji coba dengan menggunakan kartu RFID beserta sensor RFID. Sample diambil secara acak dengan kriteria/subjek penelitian yaitu mahasiswa yang scan absensi menggunakan kartu RFID sebanyak 15 orang.

\section{Komponen RFID}

Suatu sistem RFID dapat terdiri dari beberapa komponen yaitu mikrokontroler (Arduino) yang merupakan chip 
yang menjadi otak dari suatu rangkaian elektronik [7]. RFID Reader adalah alat pemindaian yang dapat membaca tag / kartu dengan benar dan mengkomunikasikan hasilnya ke mikroprosesor / mikrokontroler; dan selanjutnya adalah RFID Tag atau transponder yang terdiri dari microchip dan antena. Chip ini menyimpan nomor seri unik dan informasinya lain, tergantung pada jenis memori[8].

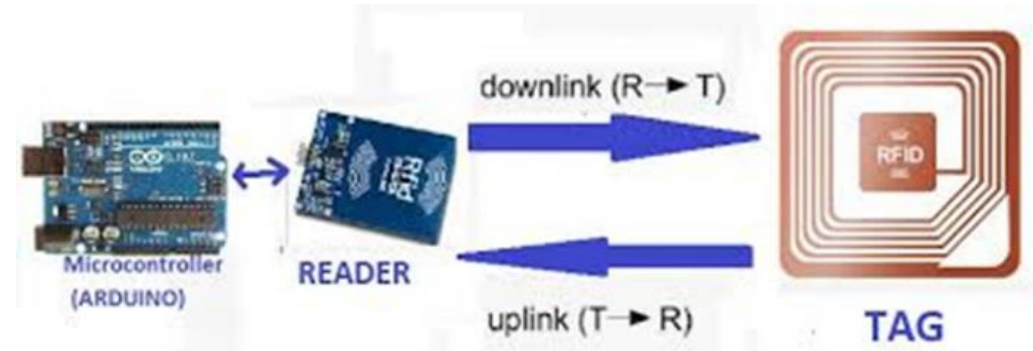

Gambar 1. Komponen RFID
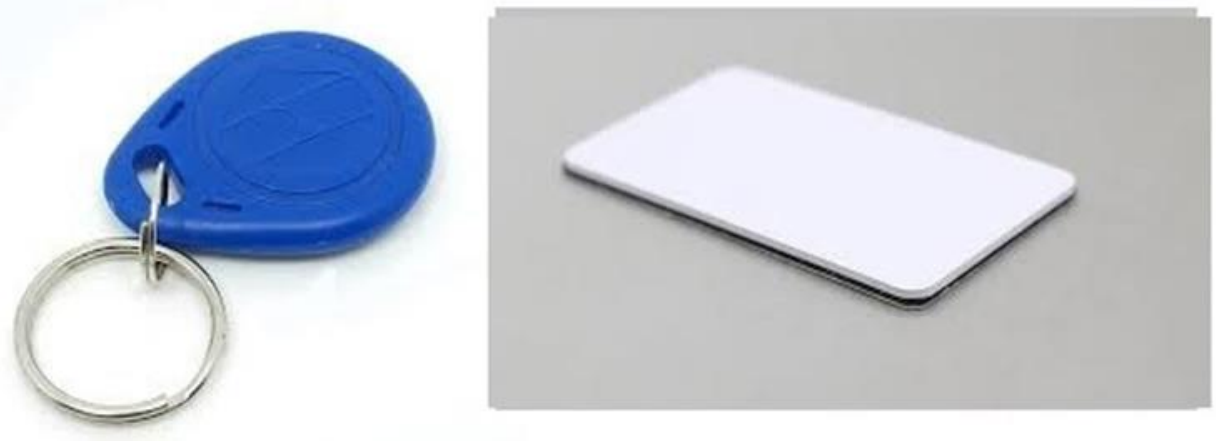

Gambar 2. Fisik Tag berupa Gantungan Kunci dan Kartu

\section{Rancangan Sistem}

Garis besar alur controlling sensor RFID menggunakan Arduino Uno dan menghubungkan data RFID ke Visual Studio 2013 dapat dilihat pada Gambar 1. Arduino Uno merupakan suatu kontrol tempat pengolahan data berupa kode RFID. Sensor RFID merupakan sensor yang digunakan untuk membaca kartu RFID dan mengirimkan data ke Arduino Uno. Input tegangan $5 \mathrm{v}$ merupakan sumber tegangan dan arus listrik. Sementara komputer dalam hal ini Visual Studio merupakan media untuk menampilkan kode RFID dan mengolahnya menjadi sistem presensi.

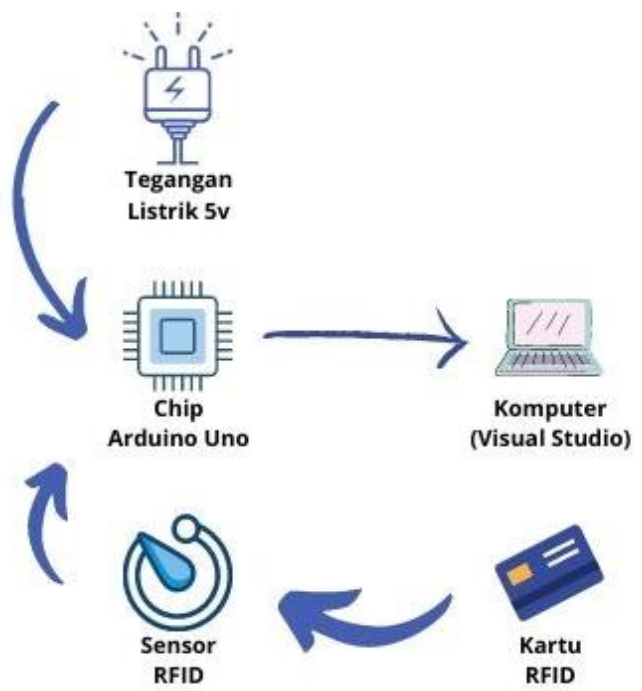

Gambar 3. Diagram Blok Kontrol Sistem Presensi RFID 


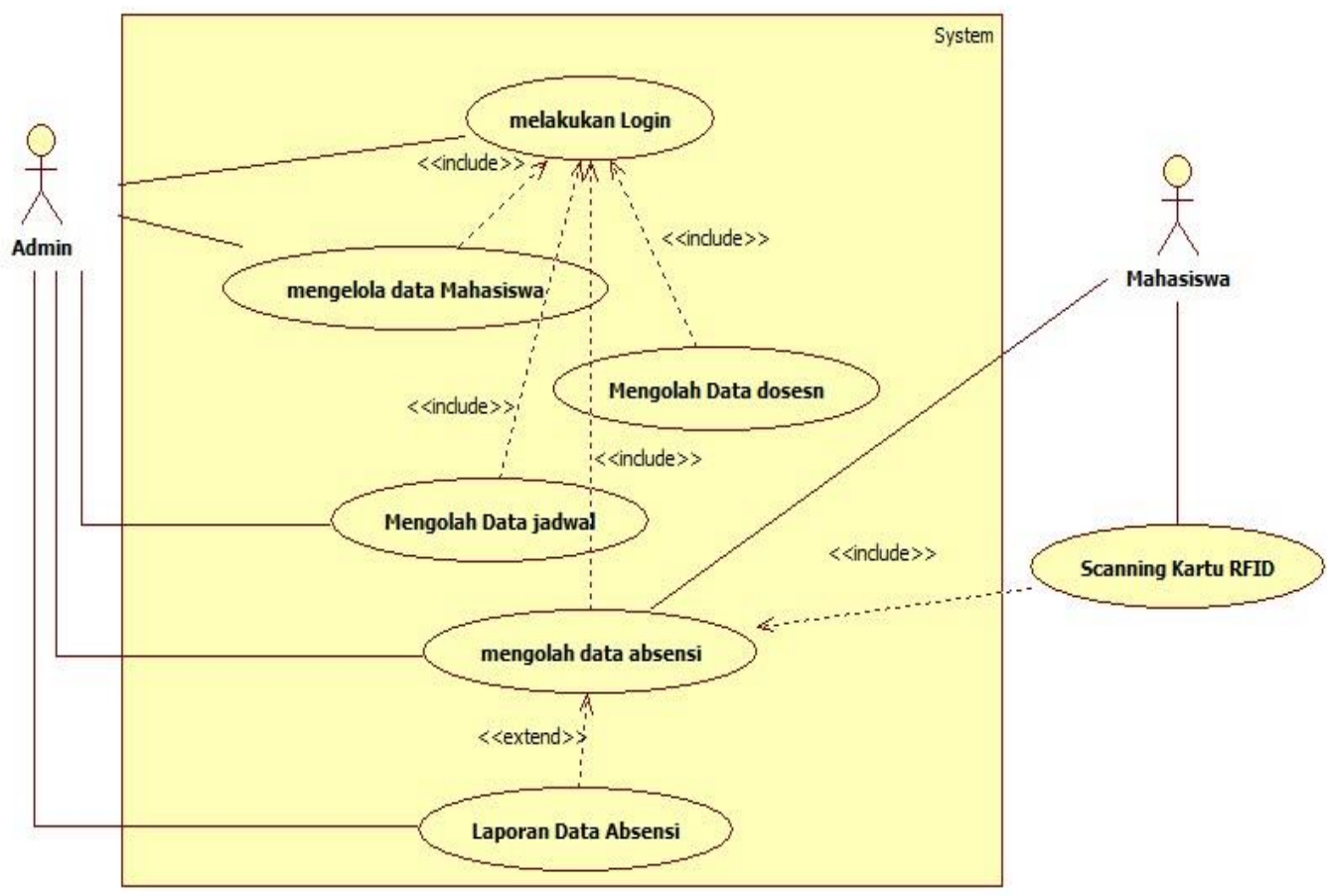

Gambar 4. Usecase Diagram Sistem Presensi RFID

Usecase diagram merupakan satu dari 13 diagram Unified Modeling Language (UML) yang digunakan untuk membantu menggambarkan rancangan proses sebuah sistem. Usecase diagram sendiri adalah uraian atau rangkaian suatu kelompok yang saling terkait dan membentuk sistem reguler yang diawasi atau dilaksanakan oleh seorang aktor. Diagram usecase ini digunakan untuk membentuk perilaku sebuah objek dalam sebuah model dan diwujudkan melalui kolaborasi[9].

Usercase diagram sistem presensi RFID menunjukkan alur proses yang dilakukan oleh admin yaitu login, mengelola data mahasiswa, mengelola data jadwal, mengelola data absensi, laporan data absensi. Sedangkan mahasiswa hanya bisa melakukan scanning kartu RFID saja.

\section{E. Rangkaian Peralatan}

Tahap instalasi terdiri dari beberapa tahap yaitu mekanika presensi dan koneksi modul elektronika yang mengacu pada desain-desain yang telah dibuat sebelumnya. Perakitan dilakukan setelah kerangka presensi selesai dibuat. Seluruh modul diletakkan sesuai dengan desain, sensor-sensor ditempatkan pada posisi yang sesuai pada kerangka pengaman pintu. Posisi sensor mempengaruhi saat sensor RFID melakukan pembacaan terhadap inputan frekuensi gelombang radio dan pembacaan kode RFID. Gambar 5 merupakan skema koneksi modulmodul elektronik sebelum terintegrasi kedalam kerangka presensi RFID.
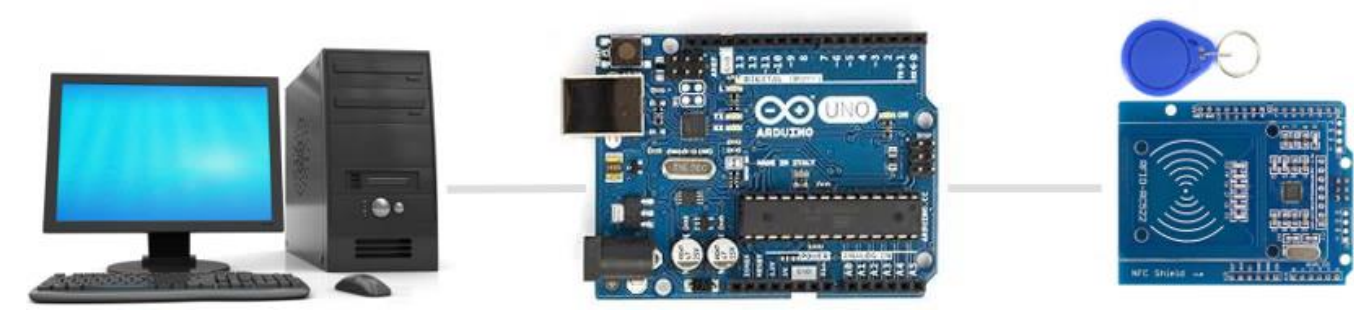

Gambar 5. Diagram Blok Kontrol Sistem Presensi RFID

\section{Hasil dan Pembahasan}

\section{A. Alur Kerja Sistem RFID}

Tahap awal mahasiswa melakukan scanning Kartu RFID pada sensor yang sudah dirangkai pada rangkaian kontrol Arduino, selanjutnya kartu RFID memancarkan frekuensi gelombang radio dan diterima oleh sensor RFID. Data yang diterima kemudian disimpan dan diolah dalam memori Arduino berupa kode hexadecimal. Pengolahan data RFID ini menggunakan bahasa pemrograman Arduino IDE 1.6.10. Tahap selanjutnya komunikasi 
perangkat Arduino[10] pada pemrograman Visual Studio 2013 dengan database Mysql dengan cara komunikasi serial port. Komunikasi serial port sendiri merupakan jembatan penghubung antara Arduino dan komputer[11].

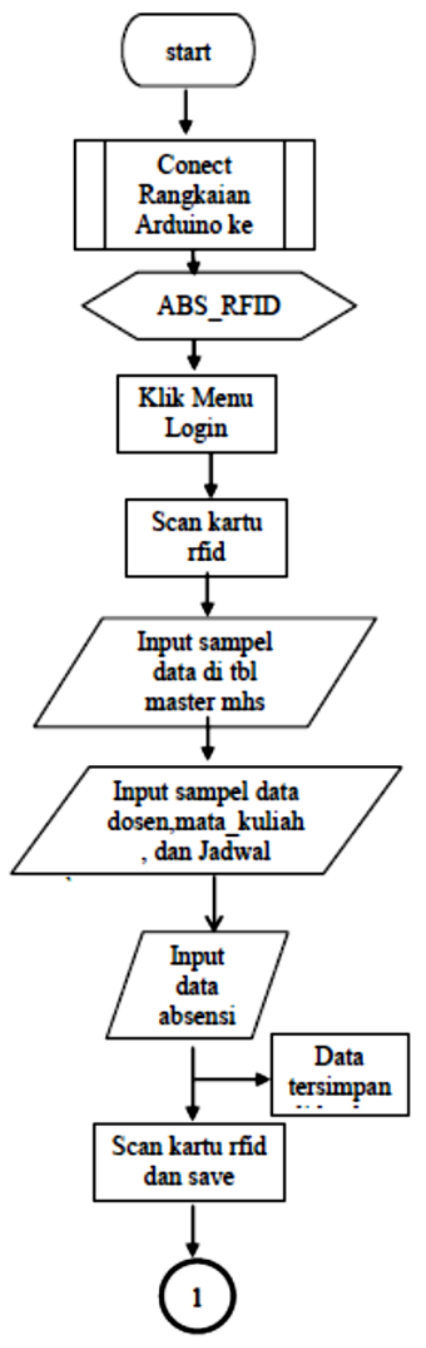

Dengan komunikasi serial port, kode RFID bisa ditampilkan di layar monitor dan disimpan kedalam database.

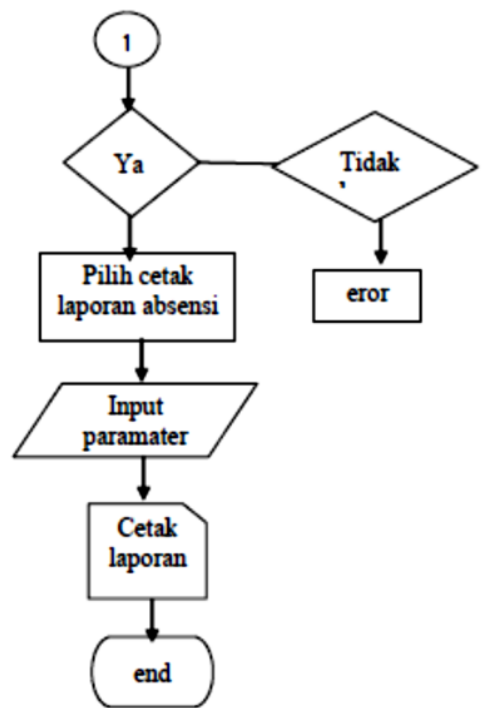

Gambar 6. Alur Cara Kerja Sistem RFID

\section{B. Alur Sistem Kerja Aplikasi Presensi}

Untuk menjalankan aplikasi presensi yaitu dengan cara menghubungkan rangkaian Arduino ke PC, setelah itu jalankan aplikasi.

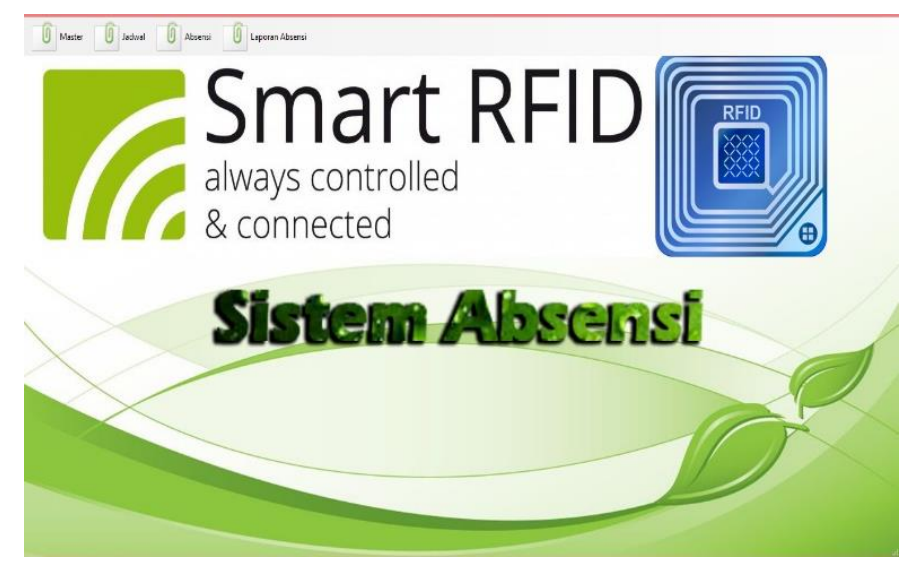


Gambar 7. Menu Utama Sistem Presensi RFID

Jika berhasil login, akan muncul menu utama dengan tampilan tabel master yang terdiri dari tabel mahasiwa, tabel dosen, tabel mata kuliah, tabel jadwal, tabel absensi, dan laporan absensi. Input data mahasiswa di tabel mahasiswa yang telah di scan menggunakan kartu RFID, input data dosen, input data mata kuliah, input data jadwal, dan otomatis data tersimpan dalam database.
Selanjutnya input data absensi di tabel absensi sesuai dengan kebutuhan. Berikutnya scan kartu RFID dan save, jika sesuai pilih button cetak laporan absensi jika tidak sesuai akan erorr. Untuk form laporan cetak absensi menggunakan parameter per jadwal yang diinginkan dan print date bisa kapan saja

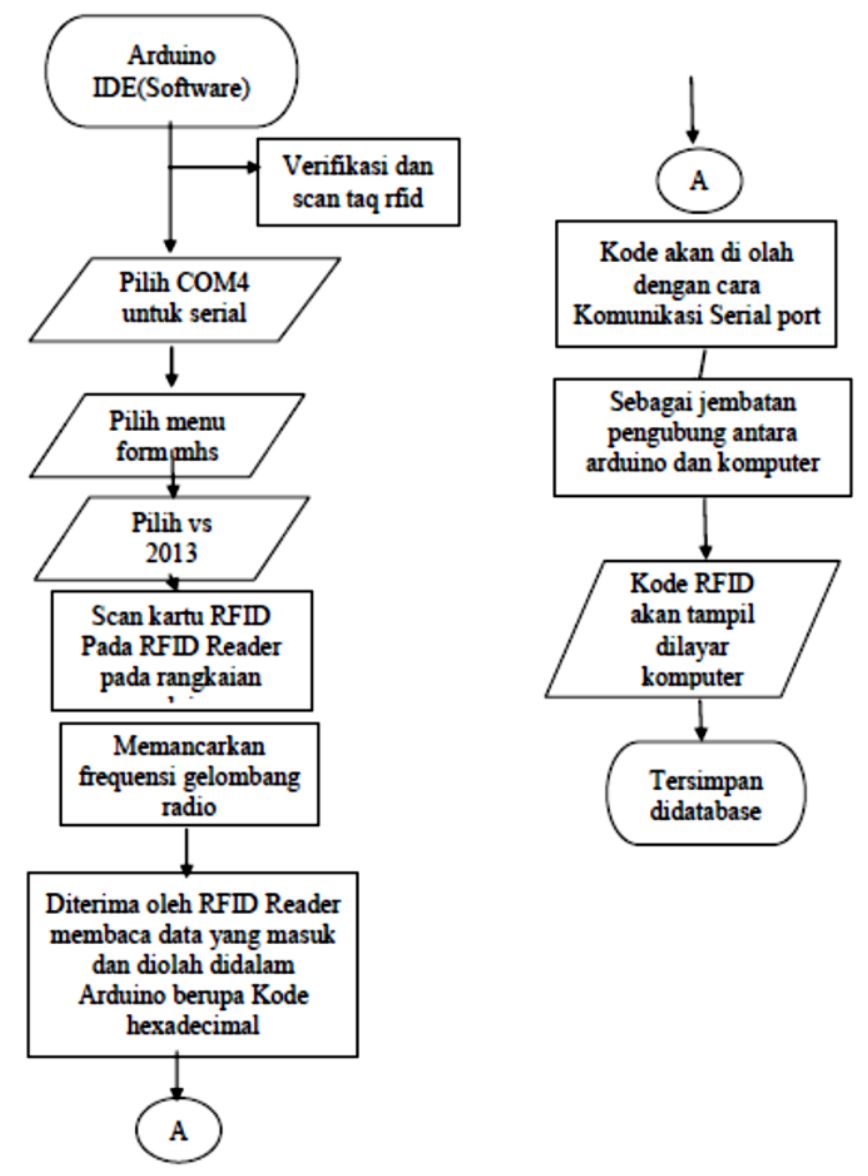

Gambar 8. Alur Sistem Kerja Aplikasi Presensi

Form presensi digunakan untuk mengelola data absensi masuk dan keluar mensetting jadwal yang sudah diinput di form input jadwal, menambah transaksi absensi, menscanning kartu RFID. Form ini berisikan tentang kode absensi, tanggal, tahun semester, pertemuan, kode jadwal, kode mk, nama mk, jam awal, jam akhir, ruang, kelas, jumlah hadir, nidm, nama dosen, hari, prodi, dan keterlambatan. 


\begin{tabular}{|c|c|c|c|c|}
\hline ○ Masuk & Kelua & 14 & & COM4 \\
\hline Setting Jadwal & Absensi & & & \\
\hline Kode Absensi & & Tahun Semester 2017 & Ruang & E.2.2.4 \\
\hline Tanggal & & 10 Agustus 2017 & Kelas & A \\
\hline Pertemuan & & $\checkmark$ & Jumlah Hadir & \\
\hline Kode Jadwal & & 0001 & NIDM & 002 \\
\hline Kode MK & & KS1100 & Nama Dosen & A.Cucus \\
\hline Nama MK & & Pemograman Web & Hari & Kamis \\
\hline Jam Awal & & 9:00:00 & Prodi & 国 \\
\hline Jam Akhir & & 11:00:00 & Keterlambatan & Menit \\
\hline
\end{tabular}

Gambar 9. Form Input Presensi

Form Presensi digunakan untuk mahasiswa melakukan kartu RFID dan juga untuk proses cetak absensi. Form scanning Kartu serta untuk menyimpan hasil scanning oleh ini berisikan Tentang ID, NPM, Nama Mahasiswa.

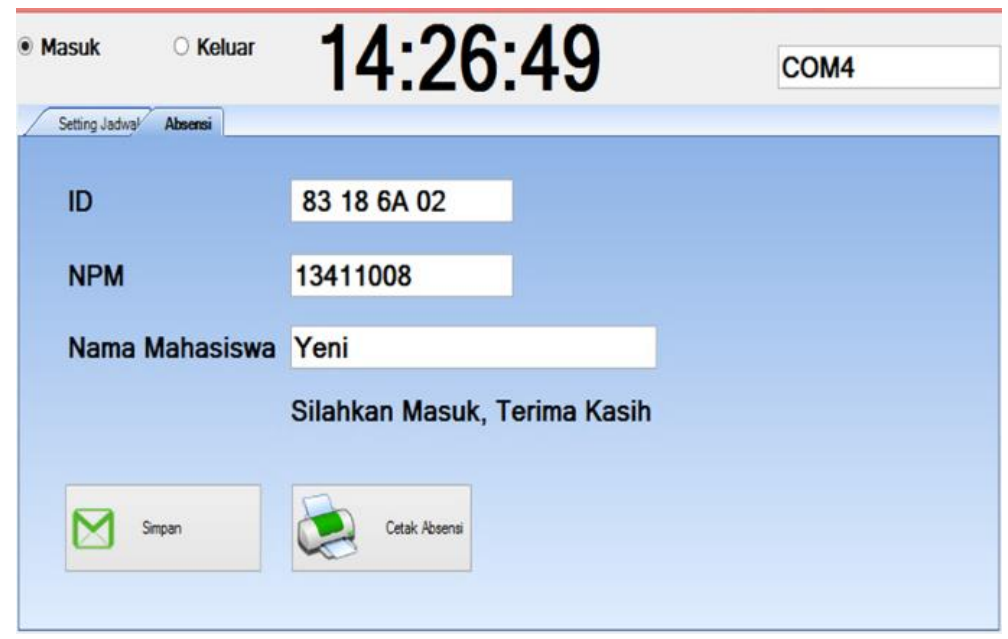

Gambar 10. Hasil Scaning Kartu RFID

Form Cetak Laporan Presensi berisikan tentang jadwal. Cetak laporan bisa kapan saja tidak harus per parameter tanggal awal dan tanggal akhir, dan enter kode bulan atau seminggu.

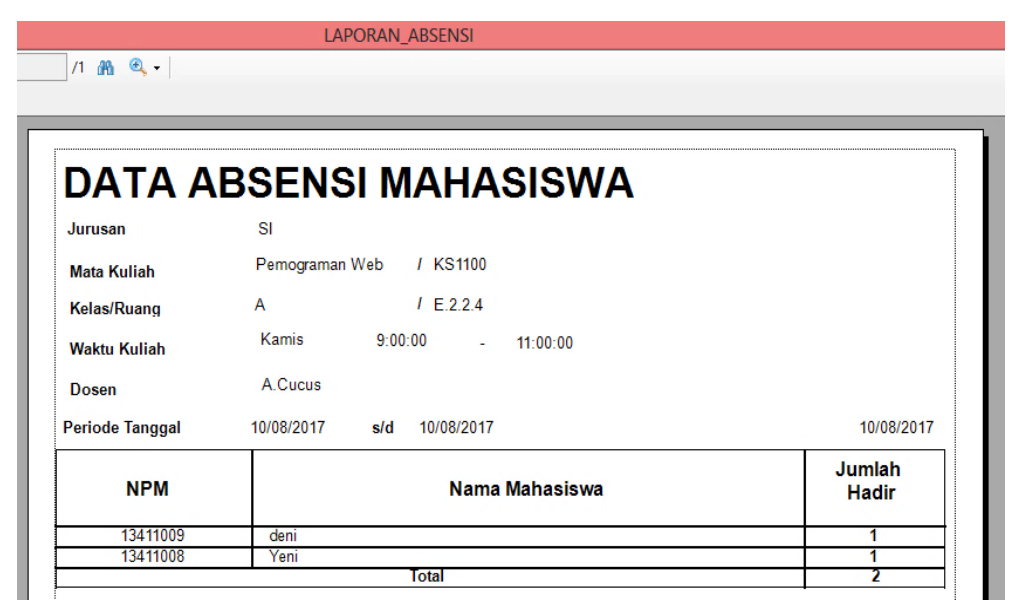

Gambar 11. Hasil Cetak Laporan Presensi per Hari 


\section{Pengujian Pretest dan Posttest}

Pengujian kemampuan awal (pretest) dan pengujian kemampuan akhir (protest) bertujuan untuk mengetahui varians antar kelompok. Untuk menguji homogenitas varians digunakan uji Arduino dan user interface. Uji homogenitas hanya digunakan pada uji parametris yang menguji perbedaan antara kedua kelompok atau beberapa kelompok yang berbeda subjeknya atau sumber datanya

Tabel 1. Hasil Uji Homogenitas Pretest dan Postest

\begin{tabular}{lccc}
\hline Variabel & Arduino & $\begin{array}{c}\text { User } \\
\text { Interface }\end{array}$ & Hasil \\
\hline Pretest & $80 \%$ & $60 \%$ & Cukup Stabil \\
Posttest & $85 \%$ & $80 \%$ & Stabil \\
\hline
\end{tabular}

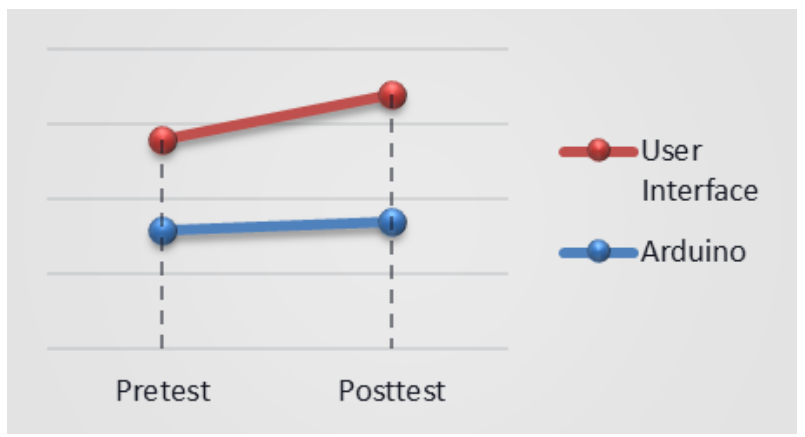

Gambar 12. Grafik Perbandingan Pretest dan Postest

Berdasarkan hasil pengujian yang telah dilakukan dapat menghasilkan perbandingan Dari hasil uji tersebut

\section{Kesimpulan}

Aplikasi presensi berbasis RFID dapat mempermudah dalam mengelola data kehadiran dan dapat mencegah terjadinya penumpukan data yang disebabkan karena data sebelumnya disimpan secara manual. Aplikasi presensi berbasis RFID juga dapat memudahkan proses penginputan kehadiran dan mempermudah dalam pengontrolan jumlah absensi.

\section{Daftar Pustaka}

[1] E. Erlangga and J. K. Putra, "Student Satisfaction Analysis Of Siater Using End User Computing Statisfaction (Eucs) ( Case Study: Bandar Lampung University)," in 3rd International Conference on Engineering \& Technology Development 2014 Faculty of Engineering and Faculty of Computer Science Bandar Lampung University, 2014, pp. 150-156, [Online]. Available: http://artikel.ubl.ac.id/index.php/icetd/article/view /353/1030.

[2] W. Susanty, T. Thamrin, E. Erlangga, and A. Cucus, "Document Management System Based on Paperless," in 1st International Conference on Engineering and Technology Development (ICETD 2012) Universitas Bandar Lampung Faculty od Engineering and Faculty of Computer Science, 2012, pp. 135-138, [Online]. Available:

http://artikel.ubl.ac.id/index.php/icetd/article/view diketahui bahwa pembacaan RFID dengan arduino dan visual studio bersifat stabil tingkat akurasinya.

$/ 101 / 101$.

[3] A. Sudewo, U. Darusalam, and N. D. Natasia, "Perancangan Sistem Absensi Mahasiswa Universitas Nasional Menggunakan Rfid Berbasis Sms Gateway Dan Atmega16," Semin. Nas. Teknol. Inf. dan Multimed. 2015, pp. 6-8, 2015.

[4] P. Paulus, W. William, V. O. Panggabean, and F. Pandi, "Sistem Absensi Berbasis Radio Frequency Identification ( Rfid ) Pada Mikroskil," I. SIFO Mikroskil, vol. 14, no. 2, pp. 129-138, 2013.

[5] E. B. Setiawan and B. Kurniawan, "Perancangan Sistem Absensi Kehadiran Perkuliahan dengan Menggunakan Radio Frequency Identification ( RFId )," vol. 1, no. 2, pp. 44-49, 2015.

[6] H. M. Jogiyanto, Analisis dan Desain Sistem Informasi Pendekatan Terstruktur Teori dan Praktik Aplikasi Bisnis. Yogyakarta: Andi Yogya, 2005.

[7] F. Djuandi, Pengenalan Arduino. Jakarta: Elexmedia, 2011.

[8] R. et al Susanto, Sistem Absensi Berbasis RFID. Jakarta: Universitas Bina Nusantara, 2009.

[9] T. Hamin, Analisis serta Perancangan Sistem Informasi Melalui Pendekatan UML. Yogyakarta: Andi Yogya, 2014.

[10] R. Y. Endra, A. Cucus, and F. N. Affandi, "The Concept and Implementation of Smart Room using Internet of things (IoT) for Cost Efficiency and 
Room Security," J. Phys. Conf. Ser., vol. 1381, no. 1, 2019, doi: 10.1088/1742-6596/1381/1/012018.

[11] R. Y. Endra, A. Cucus, F. N. Affandi, and M. B. Syahputra, "Deteksi Objek Menggunakan Histogram Of Oriented Gradient ( Hog ) Untuk
Model Smart Room," J. Explor., vol. 9, no. 2, pp. 99-105, 2018, [Online]. Available: http://jurnal.ubl.ac.id/index.php/explore/article/ view/1075. 